\title{
Christina Stachurski, Reading Pakeha? Fiction and Identity in Aotearoa New Zealand
}

Jean Anderson

\section{OpenEdition}

1 Journals

Electronic version

URL: https://journals.openedition.org/ces/8240

DOI: 10.4000/ces.8240

ISSN: 2534-6695

Publisher

SEPC (Société d'études des pays du Commonwealth)

\section{Printed version}

Date of publication: 1 April 2011

Number of pages: 154-155

ISSN: 2270-0633

\section{Electronic reference}

Jean Anderson, "Christina Stachurski, Reading Pakeha? Fiction and Identity in Aotearoa New Zealand", Commonwealth Essays and Studies [Online], 33.2 | 2011, Online since 18 November 2021, connection on 06 January 2022. URL: http://journals.openedition.org/ces/8240 ; DOI: https://doi.org/10.4000/ces. 8240

This text was automatically generated on 6 January 2022.

\section{cc) (†)}

Commonwealth Essays and Studies is licensed under a Licence Creative Commons Attribution - Pas d'Utilisation Commerciale - Pas de Modification 4.0 International. 


\title{
Christina Stachurski, Reading Pakeha? Fiction and Identity in Aotearoa New Zealand
}

\author{
Jean Anderson
}

\section{REFERENCES}

Christina Stachurski. Reading Pakeha? Fiction and Identity in Aotearoa New Zealand.

Amsterdam \& New York: Rodopi, Cross/Cultures 109, 2009. 207 p. ISBN: 9789042026445.

E-book ISBN: $9789042026452.58 .10 /$ US $\$ 77.50$

1 Title 109 in Rodopi's Cross/Cultures series is a curious combination of primary texts and approaches. Stachurski explains that she intends to examine the developing sense of Pakeha identity from the 1960s to the 1990s with particular reference to three works of fiction that captured the Kiwi imagination, and to explore the reasons for their success at particular moments in the nation's development. No one would quibble with the choice of John Mulgan's Man Alone, Keri Hulme's the bone people and Alan Duff's Once Were Warriors as iconic New Zealand texts. Nor would one take issue with Stachurski's expressed intention of arguing, after Nick Perry's 1994 affirmation, that such "exemplary works" are "forged from the interaction of a text and the audience which recognises it" (xxvi). Stachurski's avowed aim, then, is to discover "why one particular novel could catch the public's interest at a certain time" (x). The difficulty for readers of this four-part analysis (Duff's book and the film based on it being treated separately) resides in the lack of a clear and coherent set of analytical concepts.

Instead, the author proposes to follow Catherine Belsey's "new critical practice" (xxiv) in assembling aspects of disparate theories and focusing on writers' ideological propensities, as revealed by the text, along with readers' responses. She refers to Wolfgang Iser's concept of the "implied reader" (xxv), as a necessary tool for "enabl[ing] a profile of readership," since "it is impossible to research hundreds of 
thousands of individual responses and filter these through ideological climates" (xxv). Just a few pages further on, however, she makes much of Fetterley's "resisting reader" and Kuhn's idea of "reading against the grain" (xxviii), notably along gender lines. This is further complicated by reference to the differences between academic readers and "private readers" $(129,145)$ without situating these differences in relation to the key concept of the implied reader. Additionally, Stachurski proposes to consider race, although the statement that race is a construct, not a reality sits uncomfortably alongside several references in the conclusion to "actual Māori" [sic]. A new critical practice should not authorise the juxtaposition of contradictory concepts without exploring the implications of these conflicts.

These objections aside, the analyses of the three novels and the film are not without interest. Stachurski concludes that the implied reader of Man Alone is male, a bored Pākehā longing for the domains of mateship and the bush. Curiously, given the focus on explaining the book's success in terms of its "fit" with a particular New Zealand mentality, she makes frequent reference to studies of Australian pioneering spirit. Moving on to the bone people, four implied readers are identified: an anti-imperialist, a seeker of local identity, a New Age believer, and a liberal feminist. The eclecticism of Stachurski's approach leads to problematic contradictions: reference to Judith Butler's work on gender as performance is quickly followed by the claim that the subject must be dealt with "within its ideological climate, before making observations with the benefit of hindsight" (55-56), from which one assumes that despite the mention of Butler's work it is not to be taken into account. Later, references to Churchill's Top Girls (74) and Doyle's The Woman Who Walked into Doors (107) could function as footnotes but are distracting when included in the main argument. The final section on Once Were Warriors addresses "masculinism" (123) and the issues of domestic and gang violence. The statement that the implied reader would identify as Māori (148), although under ten percent of the population fits this category, raises the awkward question of why the book struck such a chord with readers, only partly answered by saying it "catered for a range of readers" (149). Factors said to contribute to the film's success include its visual reminders of "pre-1970s beer drinking lifestyle" (154) and a typically New Zealand antiauthoritarianism (159).

Turning to the conclusion, with the expectation or indeed the hope of a clarifying summary of the book's major lines of inquiry, the reader is instead confronted by a plethora of passing references to yet more texts, this time from the period 2003-2009. The final statement, that Aotearoa has moved from a bicultural to a distinctly multicultural society, and that "many more voices can be heard and the questions are more complicated" (176), has been more convincingly argued elsewhere. There are signs of inadequate editorial process: the index of works cited is inaccurate, by two pages, for the introduction, and there are a number of typographical errors. However, these are of very minor importance compared to the difficulty of following an argument that appears to be trying to cover too wide a horizon. 


\section{AUTHORS}

\section{JEAN ANDERSON}

Jean ANDERSON is Associate Professor of French and Founding Director of Te Tumu Whakawhiti Tuhinga o Aotearoa, the New Zealand Centre for Literary Translation, at Victoria University of Wellington. Her publications include co-translations into French of work by Janet Frame, Patricia Grace, Vincent O'Sullivan, Jenny Bornholdt, Fiona Kidman, Sia Figiel, John Pule, and Teresia Teaiwa, and she has a particular interest in indigenous writers of the Pacific. 